
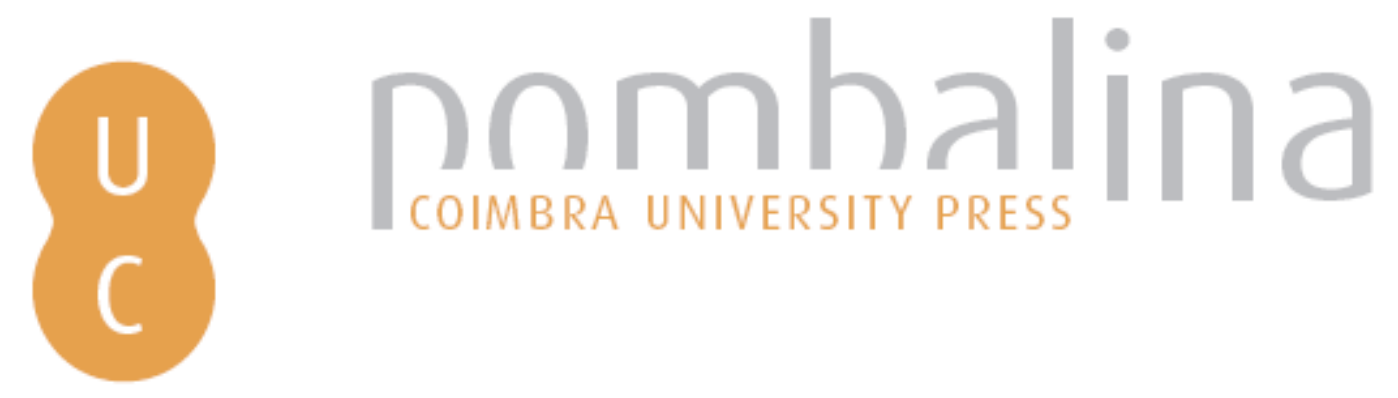

\title{
Testing the Zimbardo time perspective inventory: japanese validation study
}

Autor(es): $\quad$ Takahashi, Kiyoshi; Shimane, Masamitsu; Ono, Yoshio; Hattori, Yasuhiro

Publicado por: Imprensa da Universidade de Coimbra

URL

persistente: URI:http://hdl.handle.net/10316.2/38629

DOI: $\quad$ DOI:http://dx.doi.org/10.14195/978-989-26-0775-7_25

Accessed : $\quad$ 26-Apr-2023 13:16:41

A navegação consulta e descarregamento dos títulos inseridos nas Bibliotecas Digitais UC Digitalis, UC Pombalina e UC Impactum, pressupõem a aceitação plena e sem reservas dos Termos e Condições de Uso destas Bibliotecas Digitais, disponíveis em https://digitalis.uc.pt/pt-pt/termos.

Conforme exposto nos referidos Termos e Condições de Uso, o descarregamento de títulos de acesso restrito requer uma licença válida de autorização devendo o utilizador aceder ao(s) documento(s) a partir de um endereço de IP da instituição detentora da supramencionada licença.

Ao utilizador é apenas permitido o descarregamento para uso pessoal, pelo que o emprego do(s) título(s) descarregado(s) para outro fim, designadamente comercial, carece de autorização do respetivo autor ou editor da obra.

Na medida em que todas as obras da UC Digitalis se encontram protegidas pelo Código do Direito de Autor e Direitos Conexos e demais legislação aplicável, toda a cópia, parcial ou total, deste documento, nos casos em que é legalmente admitida, deverá conter ou fazer-se acompanhar por este aviso. 


\section{INTERNATIONAL \\ STUDIES IN TIME \\ PERSPECTIVE}

MARIA PAULA PAIXÃO

JOSÉ TOMÁS DA SILVA

(COORD.)

VICTOR ORTUÑO

PEDRO CORDEIRO

(EDITORS)

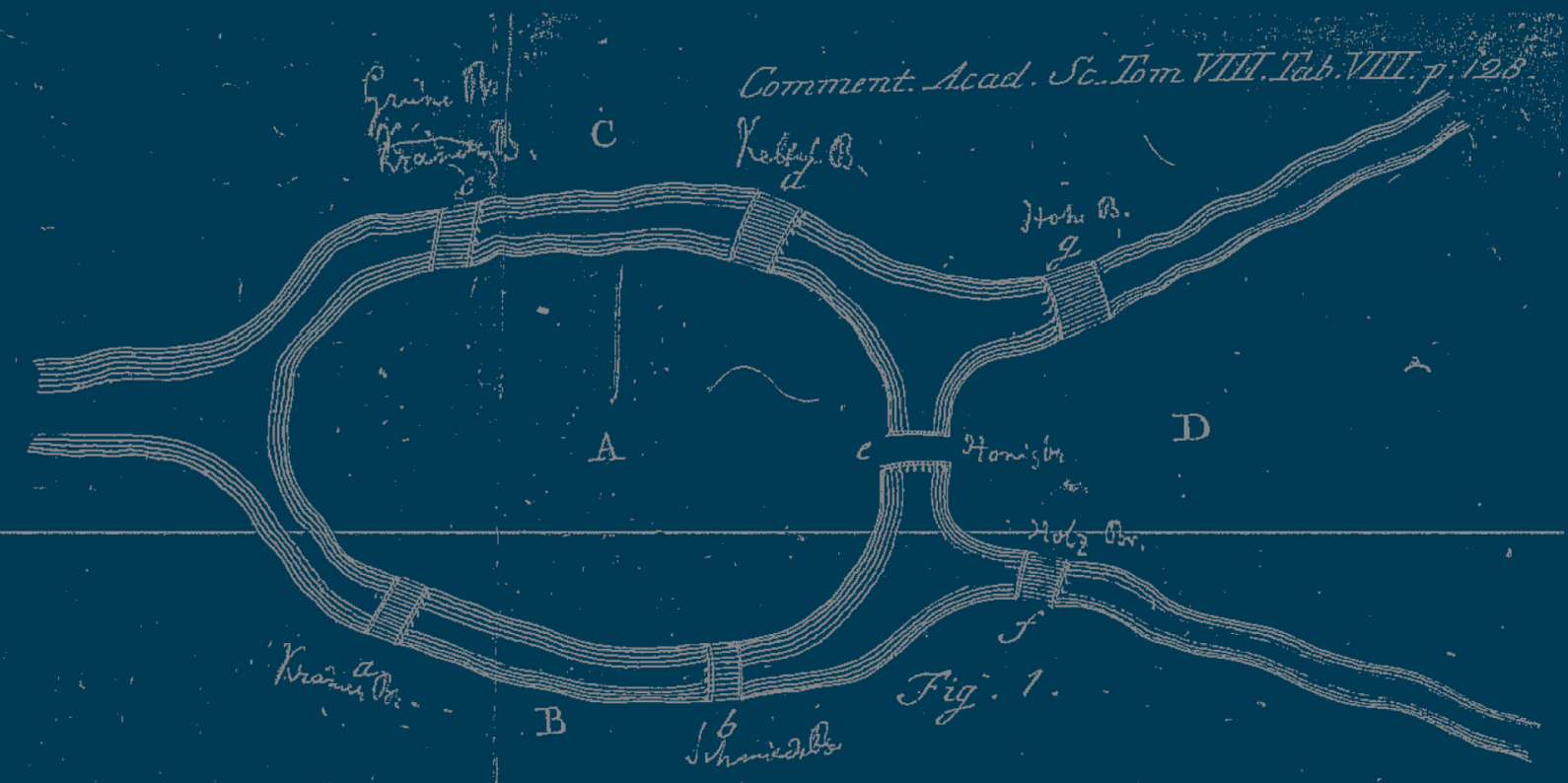

IMPRENSA DA

UNIVERSIDADE

DE COIMBRA

COIMBRA

UNIVERSITY

PRESS 
Chapter 25

Testing the Zimbardo Time Perspective Inventory: Japanese validation study

\author{
Kiyoshi Takahashi \\ Kobe University, School of Business Administration, Japan \\ ktakahas@kobe-u.ac.jp \\ Masamitsu Shimane \\ Meikai University, Japan \\ Yoshio Ono \\ Kansai University, Japan \\ Yasuhiro Hattori \\ Shiga University, Japan
}

Aвstract: The concept of time perspective has received wide acceptance in both academic and practitioner literatures since Zimbardo and Boyd published their seminal work in 1999. The number of time perspective studies has grown tremendously during the past 10 years. Although time perspective in non-Western contexts is crucial to describe human personality, much of the existing research has relied primarily on Western samples. The purpose of this study is twofold. First, reliability and validity of the Zimbardo Time Perspective Inventory (ZTPI)-Japanese version are investigated. Data collected from 1,063 Japanese workers is factor-analyzed to confirm the underlying structure of the ZTPI-J. The results found that the underlying structure for the Japanese samples was similar to the original factorial structure reported by Zimbardo and Boyd. Second, this study scrutinizes the effects of five perspectives, i.e. Past-negative, Past-positive, Present-hedonistic, Present-fatalistic, and Future, on job satisfaction, organizational commitment, intension to quit, career orientation, leadership, and organizational citizenship behavior. All five subscales were found to have significant relationships to these criteria. This study suggested the applicability of this popular measure for time perspective to the Japanese business persons.

Keywords: ZTPI-Japanese version, reliability, validity, job satisfaction, career orientation.

\title{
INTRODUCTION
}

Time perspective is an important area of research for investigating a variety of human behaviors. Its major foci have been placed on the research in educational and clinical psychology. For example, researchers have found relationships between time perspective and academic achievement (e.g., Barber, Munz, Bagsby, \& Grawitch, 2009; Joireman, 1999), the use of substances (e.g., Daugherty \& Brase, 2010; Keough, Zimbardo, \& Boyd, 1999), and depression and suicidal ideation (e.g., Laghi et al., 2009; Pluck et al., 2008). Despite 
the fact that time perspective has an explanatory power for job-related construct such as self-efficacy, planning, and goal-oriented attitudes, industrial psychologists have paid scant attention to this important notion that can describe how individuals conceptualize and value their experiences in the temporal frame of past, present, and future.

Since the introduction of the Zimbardo Time Perspective Inventory (ZTPI: Zimbardo \& Boyd, 1999), researchers all over the world have translated this inventory into different languages and tested the underlying structure of the scale empirically (e.g., Czech version, Lukavska, Klicperova-Baker, \& Lukavsky, 2011; French version, Apostolidis, Fieulaine, \& Soule, 2006; Italian version, Leghi et al., 2009, Lithuanian version, Liniauskaite \& Kairys, 2009; Swedish version, Carelli, Wiberg, \& Wiberg, 2011; and Brazilian version, Milfont et al., 2008). The review of these international studies generally found that the translated ZTPI showed the five-factor structure similar to the original model (i.e., past negative, past positive, present fatalistic, present hedonistic, and future). Therefore, it is safe to say that ZTPI is robust to measure five temporal frames even it is translated into other languages. According to the culture-bound nature of tests, however, it is necessary to examine psychometric properties such as reliability and validity if the scale is applied to the new nation with a different language.

The purpose of the present study is twofold. First, this study aims to provide evidence of the reliability and validity for the ZTPI Japanese version with data collected in industrial settings. Second, the present study follows the exploratory factor analytic procedure conducted in the original study (Zimbardo \& Boyd, 1999) to test whether the five-factor model is applicable to the Japanese samples.

\section{METHOD}

\section{Participants}

Data was collected from Japanese business persons who are registered to a major internet survey company. Research suggests that using on-line surveys is generally acceptable to survey participants and does not impact data quality when compared with paper-and-pencil surveys (Church, 2001). We recruited respondents through a Japanese internet survey company, an organization which maintains a large database of individuals willing to participate in on-line surveys. The company sent a link to our survey (URL) to Japanese business persons who volunteered to participate in the study. A total of 1,063 Japanese respondents agreed to participate in this data collection. Sexes of participants were controlled to be even, with the composition of 49.8 percent male and 50.2 percent female. Participants ranged in age from 20 to 59 with an average of 39.8 years $(s . d .=10.4)$. There was no age discrepancy between gender groups: Average age of males is 40.1 (s.d.=10.4) and of females is $39.5(s . d .=10.5)$. Composition of age groups were also controlled so as to occupy equal proportions: 20's (24.7\%), 30's (25.0\%), 40's (24.8\%), and 50's (25.4\%).

Levels of education were generally high such that more than half of the participants held a college degree. 25.6 percent received high-school education or lower, 21.1 percent with junior college education, 47.4 percent with four-year college degree, and 5.3 percent with post-graduate education. 
Most participants were rank-and-file employees (69.1\%), yet a fairly large number of management-level employees contributed to the data collection: lower management (15.8\%), middle management (6.4\%), senior management $(3.7 \%)$, and executives $(5.0 \%)$.

The levels of annual income were scattered: 3 million yen (US\$ 37,500; $\$ 1=80$ yen) or less $(36.9 \%), 3$ to 5 million yen (US\$ 37.500 to 62,$500 ; 36.4 \%$ ), 5 to 7 million yen (US\$ 62,500 to 87,$500 ; 14.9 \%$ ), and 7 million yen (US\$ 87,500) or more $(11.9 \%)$.

\section{Measures}

All participants were asked to respond to the Zimbardo Time Perspective InventoryJapanese version (ZTPI-J) that was translated by Shimojima (2010). Fifty-six items were included in an identical sequence to the original scale. In line with the original version, the ZTPI-J asks respondents to indicate how characteristic a statement is of them on a 5-point Likert scale, ranging from (1) very uncharacteristic to (5) very characteristic. Reliability of the ZTPI-J is investigated from the internal consistency approach by calculating Cronbach's alpha coefficients for each subscale.

The criterion-related validity is examined by the sizes of correlation coefficients between ZTPI-J subscales and the following outcome variables measured on the five-point Likert scales: Job satisfaction ( 5 items, $M=2.78$, s.d. $=.94$, alpha=.851); organizational commitment (6 items, $M=3.11$, s.d.=.86, alpha=.861); intention to quit (3 items, $M=3.38$, s.d. $=1.09$, alpha=.774); career orientation (3 items, $M=2.45$, s.d.=1.00, alpha=.839); leadership behavior ( 6 items, $M=2.96$, s.d.=.80, alpha=.847); and organizational citizenship behavior (OCB: 8 items, $M=3.26$, s.d.=.74, alpha=.869).

The hypothesized five-factor structure is tested empirically by following the same factoranalytic procedure taken by Zimbardo and Boyd (1999). Specifically, the present study runs a principal-component analysis with varimax rotations for testing the reproduction of subscale loading patterns for the Japanese industrial data.

\section{RESULTS}

Table 1 showed the reliability of the ZTPI-Japanese version. Cronbach's alpha coefficients were moderately high and acceptable as proof of reliable scales. Alpha coefficients ranged in size from .689 (Past Positive) to .789 (Past Negative), with an average of .726. As compared with the original reliabilities (e.g., Past Negative alpha=.82; Present Hedonistic alpha=.79; Future alpha=.77; Past Positive alpha=.80; Present Fatalistic alpha=.74 based on 361 student samples), those for the Japanese version were slightly lower.

The present study tried to validate ZTPI-J subscales by correlating them with outcome variables that were frequently researched in industrial settings. Right columns in Table 1 exhibited correlation coefficients against six popular criteria. Overall, ZTPI found significant validity coefficients with diverse criteria. Specifically, Past Negative (PN) was correlated significantly with all six variables. Interestingly, PN was related negatively with positive outcome variables (i.e., job satisfaction $r=-.243$; organizational commitment $r=-.209$; career orientation $r=-.093$; leadership $r=-.137$; and organizational citizenship 
behavior $r=-.143$ ), while a positive correlation was observed to the negative criterion (i.e., intention to quit $r=.243)$.

Present Hedonistic (PH) showed significant positive correlations against all six variables. Among others, $\mathrm{PH}$ had the strongest association with leadership behavior $(r=.301)$. This may be that because $\mathrm{PH}$ is characterized by impulsive and risk-taking attitudes, and individuals who have $\mathrm{PH}$ orientation are more likely to take leadership behavior in the situation where collectivistic and harmonious norms are salient. In other words, since leadership in this study focused on visionary/transformational behavior that emphasizes risk-taking attitudes in respondents, the relationships between $\mathrm{PH}$ and leadership may be magnified to some degree.

Similarly, Future (F) was associated significantly with all variables. It was intuitive that the planning and goal-orientated nature of $\mathrm{F}$ would have positive correlations with job satisfaction $(r=.125)$, organizational commitment $(r=.214)$, career orientation $(r=.214)$, leadership $(r=.262)$, and organizational citizenship behavior $(r=.371)$, while showing negative correlation with intention to quit $(r=-.098)$.

Past Positive (PP) found moderate positive correlations with four positive criteria (i.e., job satisfaction $r=.112$; organizational commitment $r=.122$; leadership $r=.145$; and organizational citizenship behavior $r=.100$ ). However, PP did not have statistically meaningful connections to career orientation and turnover.

Similar to the patterns of PN, Present Fatalistic (PF) exerted negative influences on positive criteria (i.e., job satisfaction $r=-.119$; organizational commitment $r=-.155$; leadership $r=-.096$; organizational citizenship behavior $r=-.101$ ) and a positive effect on intention to quit $(r=.111)$, though the magnitude of effects were lower than those of PN.

Table 1 - Reliability and validity coefficients of ZTPI-J $(n=1063)$

\begin{tabular}{|c|c|c|c|c|c|c|c|c|c|}
\hline \multirow[b]{2}{*}{$\begin{array}{l}\text { ZTPI-J } \\
\text { Factors }\end{array}$} & \multirow[b]{2}{*}{ Mean } & \multirow[b]{2}{*}{ s.d. } & \multirow[b]{2}{*}{$\begin{array}{c}\text { Cronbach } \\
\text { alpha }\end{array}$} & \multicolumn{6}{|c|}{ Criterion Variables } \\
\hline & & & & $\begin{array}{c}\text { Job Satis- } \\
\text { faction }\end{array}$ & $\begin{array}{l}\text { Organization } \\
\text { Commitment }\end{array}$ & $\begin{array}{c}\text { Intention } \\
\text { to Quit }\end{array}$ & $\begin{array}{c}\text { Career } \\
\text { Ori- } \\
\text { ent. }\end{array}$ & Leadership & $\mathrm{OCB}$ \\
\hline Past Negative & 3,11 & ,66 & ,796 & $-.243^{* * *}$ & $-.209^{* * *}$ & $.243^{* * *}$ & $-.093^{* *}$ & $-.137^{* * *}$ & $-.143^{* * *}$ \\
\hline $\begin{array}{l}\text { Present } \\
\text { Hedonistic }\end{array}$ & 3,20 & ,46 & ,736 & $.080^{* *}$ & $.153^{* * *}$ & $.088^{* *}$ & $.205^{* * *}$ & $.301^{* * *}$ & $.177^{* * *}$ \\
\hline Future & 3,45 & ,46 & ,717 & $.125^{* * *}$ & $.214^{* * *}$ & $-.098^{* *}$ & $.214^{* * *}$ & $.262^{* * *}$ & $.371^{* * *}$ \\
\hline Past Positive & 3,27 &, 57 & ,689 & $.112^{* * *}$ & $.122^{* * *}$ & -.020 & .023 & $.145^{* * *}$ & $.100^{* *}$ \\
\hline $\begin{array}{l}\text { Present } \\
\text { Fatalistic }\end{array}$ & 2,89 &, 54 & ,692 & $-.119^{* * *}$ & $-.155^{* * *}$ & $.111^{* * *}$ & -.046 & $-.096^{* *}$ & $-.101^{* * *}$ \\
\hline
\end{tabular}

${ }^{*} p<.05 ;{ }^{* *} p<.01 ;{ }^{* * *} p<.001$

In order to make a comparison of factor structures between original ZTPI and ZTPI-J, the present study replicated an exploratory principal-components factor analysis of a fivefactor solution with varimax rotations. Table 2 revealed that ZTPI-J's five factors explained 35.0 percent of the total variance. Because Zimbardo \& Boyd's exploratory factor analysis 
accounted for 35.9 percent of variance, the Japanese version was proved to have the equivalent exploratory power for the individual's temporal frame among Japanese people.

Inspection of factor loadings revealed that ZTPI-J items were loaded on the hypothesized factors successfully (bold in Table 2). However, the order of factor extraction disagreed with the original. Past Negative appeared as the first factor, as expected, followed by Future, Present Hedonistic, Present Fatalistic, and Past Positive. Despite the difference in the order of factor extraction, Table 2 suggested that ZTPI-J possessed theoretically justifiable factor structures as well as psychometrically sound properties.

Table 2 - Exploratory factor-analytic results for ZTPI-J

\begin{tabular}{|c|c|c|c|c|c|c|c|c|c|c|}
\hline \multirow{2}{*}{ ZTPI item } & \multicolumn{5}{|c|}{ Original Principal Comp. Analysis (Zimbardo \& Boyd, 1999) } & \multicolumn{5}{|c|}{ Principal Comp. Analysis (Japanese ZTPI, $n=1063$ ) } \\
\hline & $\begin{array}{c}\text { Past } \\
\text { Negative }\end{array}$ & $\begin{array}{c}\text { Present } \\
\text { Hedonistic }\end{array}$ & Future & $\begin{array}{c}\text { Past } \\
\text { Positive }\end{array}$ & $\begin{array}{l}\text { Present } \\
\text { Fatalistic }\end{array}$ & $\begin{array}{c}\text { Past } \\
\text { Negative }\end{array}$ & Future & $\begin{array}{c}\text { Present } \\
\text { Hedonistic }\end{array}$ & $\begin{array}{c}\text { Present } \\
\text { Fatalistic }\end{array}$ & $\begin{array}{c}\text { Past } \\
\text { Positive }\end{array}$ \\
\hline 1 &, 07 &, 42 &,- 02 &, 14 &,- 10 &,- 05 &, 11 & ,26 &,- 22 &, 43 \\
\hline 2 &,- 08 &, 18 & ,06 & ,62 &, 02 &, 17 &, 17 &, 15 &,- 01 & ,49 \\
\hline 3 &, 24 &, 19 & ,09 &, 14 &, 44 &, 13 &, 01 &,- 01 & ,60 &, 12 \\
\hline 4 & ,66 &,- 01 &,- 07 & 05 &, 15 & ,65 &,- 08 &,- 09 & ,13 &, 27 \\
\hline 5 & ,41 & ,00 & ,02 & 23 & ,18 & ,16 &,- 05 & ,06 &, 17 & ,23 \\
\hline 6 & ,08 &,- 16 & ,46 &, 10 & ,02 &, 04 & ,46 &, 13 & ,08 &, 00 \\
\hline 7 &,- 25 &, 14 &, 01 & ,68 &,- 02 & ,06 &, 00 & 03 & ,03 & ,70 \\
\hline 8 &, 03 &, 51 &,- 27 &,- 10 & 05 &, 24 &,- 27 &, 54 & ,08 &, 16 \\
\hline $9^{*}$ &,- 09 & ,21 &,- 33 &,- 08 &, 12 &,- 36 &,- 09 & ,43 &, 24 &,- 09 \\
\hline 10 &,- 16 &, 13 &, 56 &,- 03 &,- 09 &, 01 & ,63 &, 13 &,- 19 &, 04 \\
\hline 11 &,- 41 & ,06 & ,03 & ,63 &,- 12 &,- 42 & ,06 &, 18 &,- 07 &, 50 \\
\hline 12 & ,09 &, 32 &,- 04 &, 13 & ,22 & ,08 &, 17 & ,26 & ,16 & ,25 \\
\hline 13 &,- 08 &,- 17 & ,63 &, 04 &, 10 & ,09 &, 54 &,- 18 &, 01 &,- 06 \\
\hline 14 & ,10 &, 04 &,- 15 &,- 07 & ,64 & ,19 &,- 22 &,- 03 & ,64 & ,02 \\
\hline 15 &, 18 & ,09 & ,09 & ,63 & ,06 & ,17 &, 06 &, 04 & ,23 & ,47 \\
\hline 16 & ,69 &, 16 &,- 01 &,- 18 & ,06 &, 74 &, 04 &,- 02 &, 17 &,- 04 \\
\hline 17 &,- 20 &, 50 &, 19 &, 11 &,- 06 &,- 09 & ,48 &, 37 &, 00 &, 07 \\
\hline 18 & ,11 &, 04 &, 48 &,- 06 &,- 04 &, 05 & ,44 &,- 14 &,- 03 &, 11 \\
\hline 19 &, 05 & ,38 &, 12 &, 10 & ,07 &, 04 &, 23 &, 24 &, 27 &, 01 \\
\hline 20 &,- 24 &, 24 &, 11 & ,64 &,- 03 &,- 11 &, 12 &, 17 &,- 03 &, 59 \\
\hline 21 &,- 12 &, 04 & ,46 &, 17 &,- 04 &,- 10 &, 57 &, 04 &,- 10 &, 14 \\
\hline 22 & ,49 &, 24 &, 07 &,- 20 &,- 04 &, 36 &, 01 &, 16 &, 27 &,- 27 \\
\hline 23 &, 07 &, 51 &,- 25 &,- 12 &, 13 &, 23 &,- 35 & ,41 &, 17 &, 15 \\
\hline $24^{*}$ &, 06 & ,28 &,- 49 &,- 11 &, 20 &, 18 &,- 51 &, 23 &, 29 &, 03 \\
\hline $25^{*}$ &, 55 &,- 02 &, 02 &,- 52 &, 21 & ,60 & 00 &, 02 &, 35 &,- 31 \\
\hline 26 &, 05 &, 56 &, 05 &, 18 &,- 14 & ,08 &, 15 &, 57 &,- 23 &, 16 \\
\hline 27 &, 55 &, 03 &,- 18 &, 05 & ,02 &, 58 &,- 08 &, 15 &,- 02 &, 02 \\
\hline 28 &, 00 &, 36 &,- 30 &, 06 &, 33 &,- 12 &,- 05 &, 40 &, 21 &, 10 \\
\hline 29 &, 04 &, 06 &,- 02 & ,64 &, 21 & ,29 &,- 05 &, 02 & ,03 & ,66 \\
\hline
\end{tabular}




\begin{tabular}{|c|c|c|c|c|c|c|c|c|c|c|}
\hline \multirow{2}{*}{ ZTPI item } & \multicolumn{5}{|c|}{ Original Principal Comp. Analysis (Zimbardo \& Boyd, 1999) } & \multicolumn{5}{|c|}{ Principal Comp. Analysis (Japanese ZTPI, $n=1063$ ) } \\
\hline & $\begin{array}{c}\text { Past } \\
\text { Negative }\end{array}$ & $\begin{array}{c}\text { Present } \\
\text { Hedonistic }\end{array}$ & Future & $\begin{array}{c}\text { Past } \\
\text { Positive }\end{array}$ & $\begin{array}{c}\text { Present } \\
\text { Fatalistic }\end{array}$ & $\begin{array}{c}\text { Past } \\
\text { Negative }\end{array}$ & Future & $\begin{array}{c}\text { Present } \\
\text { Hedonistic }\end{array}$ & $\begin{array}{c}\text { Present } \\
\text { Fatalistic }\end{array}$ & $\begin{array}{c}\text { Past } \\
\text { Positive }\end{array}$ \\
\hline 30 & ,08 & ,03 & ,37 &, 16 &,- 29 &, 17 & ,38 &,- 12 &,- 05 &, 18 \\
\hline 31 &, 00 & ,70 &,- 02 &, 00 &, 03 & ,06 & ,16 & ,60 &, 00 &,- 01 \\
\hline 32 &,- 13 & ,45 &,- 08 & ,08 &, 15 &,- 15 &, 27 & ,36 &,- 14 &, 12 \\
\hline 33 & ,43 &, 04 &,- 17 &,- 08 & ,29 &, 52 &,- 09 & ,00 & ,26 &,- 08 \\
\hline 34 & ,67 &,- 01 &, 05 &,- 25 & ,07 & ,68 & ,01 &,- 01 & 13 &,- 06 \\
\hline 35 & ,20 & ,16 &,- 20 &,- 09 & ,42 & ,28 &,- 02 & ,07 & ,35 & ,03 \\
\hline 36 & ,47 & ,08 & ,06 &, 24 & ,21 &, 52 & ,02 & ,07 & ,19 & ,22 \\
\hline 37 & ,14 &, 17 &,- 12 &,- 04 & ,59 &, 11 &,- 07 & ,02 & ,59 & ,00 \\
\hline 38 & ,17 &,- 02 & ,06 &, 02 & ,73 & ,26 &,- 02 &,- 07 & ,61 & ,05 \\
\hline 39 & ,04 &,- 02 &,- 01 &,- 10 & ,68 &,- 14 &,- 04 & ,19 & ,44 &,- 11 \\
\hline 40 &,- 17 &,- 02 & ,61 &,- 01 &, 04 &,- 03 &, 56 &,- 08 & ,09 & ,08 \\
\hline $41^{*}$ & ,00 & ,00 & ,00 &,- 45 &, 25 & ,16 & ,00 & ,18 &, 32 &,- 30 \\
\hline 42 & ,00 & ,71 &,- 01 &,- 04 & ,08 & ,08 & ,15 & ,67 &,- 07 &, 05 \\
\hline 43 &,- 05 & ,07 &, 45 & ,07 &,- 05 &, 04 &, 50 &, 15 &,- 05 & ,04 \\
\hline 44 & ,18 & ,45 &,- 10 & ,07 &, 12 &, 13 &,- 18 & ,41 & ,21 & ,15 \\
\hline 45 &,- 16 &,- 09 & ,61 &,- 06 &,- 06 &,- 18 &, 56 & ,00 &,- 02 & ,06 \\
\hline 46 &, 16 & ,44 &,- 22 & ,23 & 10 & ,29 &,- 15 & ,37 &, 14 & ,08 \\
\hline 47 & ,20 &,- 09 & ,00 & ,09 &, 42 & ,26 & ,06 &, 01 & ,30 & ,21 \\
\hline 48 &,- 04 & ,45 &,- 16 &,- 10 & ,18 & ,00 &,- 21 & ,37 &, 25 & ,08 \\
\hline 49 &, 10 &,- 06 &, 11 &, 47 &,- 03 &,- 20 & ,17 & ,09 & ,03 & ,44 \\
\hline 50 & ,76 & ,06 & ,06 &,- 08 &, 05 & ,71 &, 05 &,- 03 & ,02 & ,09 \\
\hline 51 & ,09 &,- 07 &, 51 &, 01 &,- 08 &,- 15 &, 52 & ,32 &,- 15 &,- 05 \\
\hline 52 &,- 05 & ,28 &,- 18 &,- 04 &, 34 &,- 11 &,- 17 & ,39 & ,26 &,- 10 \\
\hline 53 & ,08 &, 14 &,- 11 & ,02 &, 45 & ,19 &,- 11 &, 10 &, 52 & ,03 \\
\hline 54 & ,63 &,- 07 &,- 13 & ,01 &, 21 & ,49 &,- 06 &, 11 &, 10 & ,37 \\
\hline 55 & ,20 & ,44 & ,00 & ,07 &,- 02 & ,05 &, 10 &, 47 &,- 05 & ,20 \\
\hline $56^{*}$ &,- 11 & ,29 &,- 36 & ,09 & ,10 &,- 22 & ,03 &, 35 & ,23 & ,00 \\
\hline eigen value & 6,86 & 5,01 & 3,54 & 2,50 & 2,21 & 6,57 & 4,87 & 3,56 & 2,63 & 1,95 \\
\hline$\%$ explained & 12,3 & 8,9 & 6,3 & 4,5 & 3,9 & 11,7 & 8,7 & 6,4 & 4,7 & 3,5 \\
\hline
\end{tabular}

\section{Discussion}

The aim of this study was to examine the reliability and validity of the Japanese version of the ZTPI, and to investigate its factor structure in the sample of Japanese workers. 
Results found that ZTPI-J exhibited reasonably high internal consistency and high validity with six outside criteria, including job satisfaction, organizational commitment, intention to quit, career orientation, leadership, and organizational citizenship behavior.

In addition, results of exploratory factor analysis indicated that the five-factor structure proposed by Zimbardo and Boyd (1999) had a fit to the data collected from Japanese industrial participants, providing statistical evidence for a justifiable factor structure, confirmative loading patterns, and a significant explanatory power. Therefore, the present study was able to give empirical support for testing the applicability of ZTPI in international, industrial settings.

Regarding its applicability to an industrial sample, Ryack (2012) tested the ZTPI structure with the data from professional financial advisors, yet failed to support the fit of theoretical models suggested by prior research. According to the findings in this study, however, the original five-factor ZTPI seems to fit well to the business persons. Though researchers have often suggested significant differences between student samples and occupational samples, the present study refuted such an assumption and suggested the generalizability of this popular measure of temporal frame across cultural and situational differences.

\section{REFERENCES}

Apostolidis, T., Fieulaine, N., \& Soule, F. (2006). Future time perspective as predictor of cannabis use: Exploring the role of substance perception among French adolescents. Addictive Behavior, 31, 2339-2343.

Barber, L. K., Munz, D. C., Bagsby, P. G., \& Grawitch, M. J. (2009). When does time perspective matter? Self-control as a moderator between time perspective and academic achievement. Personality and Individual Differences, 46, 250-253.

Carelli, M. G., Wiberg, B., \& Wiberg, M. (2011). Development and construct validation of the Swedish Zimbardo Time Perspective Inventory. European Journal of Psychological Assessment, 27, 220-227.

Church, A. H. (2001). Is there method to our madness: the impact of data collection methodology on organizational survey results. Personnel Psychology, 54, 937-969.

Daugherty, J. R., \& Brase, G. L. (2010). Taking time to be healthy: Predicting health behaviors with delay discounting and time perspective. Personality and Individual Differences, 48, 202-207.

Jorreman, J. (1999). Additional evidence for validity of the consideration of future consequences scale in an academic setting. Psychological Reports, 84, 1171-1172.

Keough, K. A., Zimbardo, P. G., \& Boyd, J. N. (1999). Who's smoking, drinking, and using drugs? Time perspective as a predictor of substance use. Basic and Applied Social Psychology, 21, 149-164

Laghi, F., Baiocco, R., D’Alessio, M., \& Gurrieri, G. (2009). Suicidal ideation and time perspective in high school students. European Psychiatry, 24, 41-46.

Liniauskaite, A., \& Kairys, A. (2009). The Lithuanian version of the Zimbardo Time Perspective Inventory (ZTPI). Psichologija, 40, 66-86.

Lukavska, K., Kuicperova-Baker, M., \& Lukavsky, J. (2011). ZTPI-Zimbardo Time Perspective Inventory: Czech validization study. Ceskoslovenska Psychologie, 55, 356-373.

Milfont, T. L., Andrade, P. R., Belo, R. P., \& Pessoa, V. S. (2008). Testing Zimbardo Time Perspective Inventory in a Brazilian sample. Revista Interamericana de Psicologia, 42, 49-58. 
Pluck, G., Lee, K. H., Lauder, H. E., Fox, J. M., Spence, S. A., \& Parks, R. W. (2008). Time perspective, depression, and substance misuse among the homeless. Journal of Psychology, 142, 159-168.

RyaCK, K. (2012). Evidence that time perspective factor depend on the group: Factor analysis of the CFC and ZTPI scales with professional financial advisors. Personality and Individual Differences, 52, 723-727.

Shimojima, Y. (2010). Time perspective and health behavior: An use of Zimbardo Time Perspective Inventory Japanese version. Paper presented at the annual meeting of the Japanese Association of Educational Psychology (in Japanese).

Zimbardo, P. G., \& Boyd, J. N. (1999). Putting time in perspective: A valid, reliable individualdifferences metric. Journal of Personality and Social Psychology, 77, 1271-1288. 